\title{
Crop Water Requirement, Water Productivity and Comparative Advantage of Crop Production in Different Regions of Uttar Pradesh, India
}

\author{
Maina Kumari ${ }^{1 *}$, O.P. Singh ${ }^{1}$ and Dinesh Chand Meena ${ }^{2}$ \\ ${ }^{1}$ Department of Agricultural Economics, Institute of Agricultural Sciences, \\ Banaras Hindu University, Varanasi - 221005, Uttar Pradesh, India \\ ${ }^{2}$ Agricultural Economics, Indian Institute of Soil and Water Conservation, Research Centre, \\ Agra, Uttar Pradesh, India \\ *Corresponding author
}

\begin{tabular}{|c|c|}
\hline & A B S T R A C T \\
\hline & $\begin{array}{l}\text { The growing physical water scarcity would further hamper the food security. Over the past } \\
\text { few years, the concept of water productivity in agriculture has gained ground with a shift } \\
\text { from land productivity to water productivity due to increasing shortage of irrigation water } \\
\text { productivity. The objective of the study was to estimate consumptive water use and }\end{array}$ \\
\hline Keywords & $\begin{array}{l}\text { agronomic water productivity for different crops grown in different regions of Uttar } \\
\text { Pradesh and to identify the regions for comparative advantage of crop production based on }\end{array}$ \\
\hline $\begin{array}{l}\text { Crop water } \\
\text { requirement, } \\
\text { Water productivity } \\
\text { and Comparative } \\
\text { advantage. }\end{array}$ & $\begin{array}{l}\text { water productivity and crop yield. The study was based on the secondary data and it was } \\
\text { collected from different sources. The Crop Wat model was used for estimation of } \\
\text { consumptive water requirement for crop production. The results showed that among kharif } \\
\text { crops, highest crop water requirement was found for paddy crop in Bundelkhand region, }\end{array}$ \\
\hline Article Info & rabi season, highest crop water requirement was estimated for wheat crop in Bundelkhand \\
\hline $\begin{array}{l}\text { Accepted: } \\
\text { 21 June } 2017 \\
\text { Available Online: } \\
\text { 10 July } 2017\end{array}$ & $\begin{array}{l}\text { region and minimum water requirement was estimated for barley crop in Western region. } \\
\text { Almost all kharif crops were depicting comparative advantage from water productivity } \\
\text { point of view in Eastern region, while among these crops most of the crops were depicting } \\
\text { comparative advantage from yield point of view in Central region. Gram and sesamum has }\end{array}$ \\
\hline & $\begin{array}{l}\text { comparative advantage in Eastern region, soybean in central region, moong }(\mathrm{k}) \text { in } \\
\text { Bundelkhand region and maize }(\mathrm{k}) \text {, wheat, barley, pea and beans, lentil, rapeseed-mustard, } \\
\text { maize }(\mathrm{z}) \text { and sugarcane in western region from both water productivity and crop yield } \\
\text { point of view. }\end{array}$ \\
\hline
\end{tabular}

\section{Introduction}

Water is the most critical resource for agriculture, gaining primacy even over soil. It is essential for sustaining all forms of life, food production, economic development, and for general wellbeing. Water availability within the country varies widely from region to region as a result of rainfall, groundwater reserve and proximity to river basins, which will have its own effect on water use efficiency and water allocation. The average annual rainfall in the country is about 1170 $\mathrm{mm}$ with extremely irregular with respect to time and area.

Agriculture is largest user of water resources accounting for about 80 per cent of the total water withdrawal. Among the different sources of irrigation water, groundwater is 
playing an important role in the India's irrigated farming, which contributes about 60 per cent of the net cultivated area is irrigated by groundwater (Shah et al., 2006). Water is a finite resource the availability of which is declining with each passing day. The per capita water availability in 2001 was $1820 \mathrm{~m}^{3}$ per year and it is projected that by 2025 , the per capita water availability will further reduce significantly to $1341 \mathrm{~m}^{3}$ and to 1140 $\mathrm{m}^{3}$ in 2050 (Bhattacharyya et al., 2015). Going by Falkenmark criteria, most of the Indian states will have reached the water stress condition by 2025 and almost water scarcity condition by 2050 . A total renewable water resource of Uttar Pradesh was 77.19 BCM in 2011 and it is varying from region to region. The highest total renewable water resource was found in western region (28.93 BCM) followed by eastern region (27.60 $\mathrm{BCM})$, central region $(15.86 \mathrm{BCM})$ and lowest in Bundelkhand region (4.80 BCM) (Anonymous, 2014). The scarcity of water would further hamper the food security, as the scarcity of water will directly suppress agricultural production. Growing physical shortage of water on the one hand, and scarcity of economically accessible water owing to increasing cost of production and supply of the resource on the other, had preoccupied researchers with increasing productivity of water use in agriculture in order to get maximum production or value from every unit of water used.

The water productivity is relevant to economists and engineers who are interested in evaluate the sustainability and efficiency of agricultural water management in terms of "produced yields per unit of water used", often referred to as "crop per drop". Its help to identify disproportionate water use or water limited yield gaps and thereby support improvements in agricultural water management. The term crop-water productivity used in the literature as physical water productivity expressed in kilogram of crop produce from one cubic meter of water used or diverted $\left(\mathrm{kg} / \mathrm{m}^{3}\right)$ and combined physical and economic water productivity of water expressed as net or gross present value of crop produce per cubic meter of water (Rs./m³) (Kumar et al., 2008).

Since each region of the Uttar Pradesh state has a combination of problems and potentials for water resources, and hence recommendations can be suggested on a region basis. Regional planning of water resources could be achieved, only if we have more precise scientific data about the crop water requirements at different stages, quantity of water needed for producing targeted yields specific to crops.Hence, this study has taken with following objectives: [1] To estimate the consumptive water use for crop production in different regions of Uttar Pradesh; [2] To work out the physical water productivity of different crop grown in different regions of Uttar Pradesh; and [3] To find out the comparative advantage of the crop production based on water productivity, crop yield and both crop yield and water productivity.

\section{Materials and Methods}

Several studies are available which deals with water productivity of crops with respect to evapo-transpiration (ET) from crops (Kijne et al., 2002). Yihun (2015) analyzed the water productivity for irrigated teff; Zwart (2010) analyzed water productivity of rain-fed and irrigated wheat and Carr (2016) analyzed water productivity in irrigated corn.

\section{Data and sources}

Present study was based on the secondary data and data related to the cropped area, production and yield of major crops etc. were collected from the various sources which 
were published by Economic and Statistics Division, Ministry of Agriculture and Farmer Welfare, Government of India, Government of Uttar Pradesh for the year 2013-14.

\section{Estimation of crop water requirement}

Crop water requirements of major crops in different regions of state were estimated by using FAO model Crop Wat. It uses the FAO Penman-Monteith method (Equation 2) for calculating the reference crop evapotranspiration $\left(\mathrm{ET}_{0}\right)$, and gives values that matches with the actual need of the crop water use data worldwide, also being reproducible (Allen et al., 1998; Allen et al., 2006; Lopez et al., 2012). The crop water requirement (CWR) was measured in $\mathrm{m}^{3} / \mathrm{ha}$ was calculated from the accumulated crop evapo-transpiration (ETc) measured in $\mathrm{mm}$ /day over the complete crop growing period. The evapo-transpiration (ETc) was calculated by using following formula:

$\mathrm{ET}_{\mathrm{c}}=\mathrm{K}_{\mathrm{c}} * \mathrm{ET}_{0} \ldots \ldots \ldots \ldots \ldots$ (1)

Where $\mathrm{ET}_{0}$ is crop reference evapotranspiration and $\mathrm{Kc}$ is crop coefficients. Reference crop evapo-transpiration was calculated on the basis of following FAO Penman-Monteith:

$$
E T_{0}=\frac{0.408 \Delta\left(R_{n}-G\right)+\gamma \frac{900}{273} U_{2}\left(e_{a}-e_{d}\right)}{\Delta+\gamma\left(1+0.34 U_{2}\right)} .
$$

Where, $E T_{0}$ is Reference crop evapotranspiration ( $\mathrm{mm} /$ day); $R_{n}$ is Net radiation at the crop surface $\left(\mathrm{MJ} / \mathrm{m}^{3} /\right.$ day); $G$ is Soil heat flux $\left(\mathrm{MJ} / \mathrm{m}^{3} /\right.$ day $) ; T$ is Average air temperature $\left({ }^{0} \mathrm{C}\right) ; U_{2}$ is Wind speed measured at $2 \mathrm{~m}$ height $(\mathrm{M} / \mathrm{S}) ; e_{a}$ is Saturation Vapour Pressure Curve $(\mathrm{kPa}) ; e_{d}$ is Actual Vapour pressure $(\mathrm{kPa}) ; e_{a} e_{d}$ is Vapour pressure deficit $(\mathrm{kPa}) ; \Delta$ is slope of the vapour pressure curve $\left(\mathrm{kPa} /{ }^{0} \mathrm{C}\right)$ and $\Gamma$ is Psychometric Constant $\left(\mathrm{kPa} /{ }^{0} \mathrm{C}\right)$.

\section{Estimation of crop water productivity}

The physical water productivity for a given crop $\left(\mathrm{kg} / \mathrm{m}^{3}\right)$ was estimated across the different regions of Uttar Pradesh by using the data on crop yield and the estimated volume of consumptive water used for crop production. The physical productivity of water was estimated by using following equation:

$W P_{\text {crop }}=\frac{Q_{\text {crop (main })}}{\theta_{\text {crop }}}$

Where, $W P_{\text {crop }}$ is the water productivity $\left(\mathrm{Kg} / \mathrm{m}^{3}\right)$ for crop; $Q_{\text {crop (main) }}$ is the average yield of crops in $\mathrm{Kg}$; $\theta_{\text {crop }}$ is the total volume of water used for crop production.

\section{Results and Discussion}

\section{Region-wise consumptive water use}

The results of Crop Wat model gives consumptive water use and it does not includes water losses during water supply from source to crop field i.e. evaporation, percolation, seepage loses from conveyance channel. Water requirements for various crop productions are influenced by the various factors viz. area share of different crops, climatic factors (temperature, wind velocity, relative humidity, sunshine and rainfall), crop variety, crop duration and soil structure.. Besides these, agronomic practices and plant physiology also affects the water consumption by the crops. Thus, these factors lead to difference in the consumptive water use for the same crop in different regions

Most of the crops growing during the kharif season are using more green water (rainfall) 
and supplemented by blue water (artificial irrigation), whereas crops grown in rabi and zaid seasons were catering water requirement from irrigation water and somewhat fulfilled by off season rainfall for their crop cycle (Table 1). The major crops grown during kharif season were rice, maize, jowar, small millets and wheat, barley in rabi season.

Among the kharif crops, highest crop water requirement was estimated to be $9130 \mathrm{~m}^{3} / \mathrm{ha}$ for rice crop in Bundelkhand region, whereas minimum crop water requirement was observed for jowar in Western region with $3565 \mathrm{~m}^{3} / \mathrm{ha}$. While, in rabi season highest crop water requirement was estimated for wheat crop in Bundelkhand region (8286 $\mathrm{m}^{3} / \mathrm{ha}$ ) and minimum for barley crop with $2219 \mathrm{~m}^{3} /$ hain Western region.

The major pulse crops grown by the farmers in different regions of Uttar Pradesh were arhar, moong and urd in kharif season, whereas, gram, pea, peas and beans and lentil inrabi season. The upper most crop water requirement for kharif pulses was in Western region, while bottom most was in Central region with an amount of $4142 \mathrm{~m}^{3} /$ ha and $3765 \mathrm{~m}^{3} /$ ha, respectively.

Among oilseeds, sesame, groundnut and soybean were grown during kharif season, whereas, rapeseed-mustard, linseed and castor grown in rabi season across different regions of Uttar Pradesh. It was found that among the kharif oilseed crops groundnut was devouring highest crop water requirement in Bundelkhand region (4681 $\left.\mathrm{m}^{3} / \mathrm{ha}\right)$. In contrast, soybean was minimum water required crop with $4596 \mathrm{~m}^{3} /$ ha in Eastern region. The cash crop includes potato (r), tobacco $(\mathrm{r})$, sugarcane $(\mathrm{k})$ and cotton $(\mathrm{k})$ also grown in state. Among these crops, sugarcane crop in Bundelkhand region was registered highest crop water requirement with 18492 $\mathrm{m}^{3} /$ ha and tobacco crop have minimum water requirement in Western region of Uttar Pradesh with $2278 \mathrm{~m}^{3} /$ ha.

In Uttar Pradesh, crops also grown in zaid season and the crops are rice, maize, moong, urd and sunflower. Among these crops, area share of rice and sunflower was very small as compared to urd, moong and maize. Zaid cereal embraces maize and rice and zaid pulses comprises of moong and urd while there was only one crop grown in zaid oilseed i.e. sunflower (Table 1). Among zaid cereal rice have highest crop water requirement in Central region with $11461 \mathrm{~m}^{3} /$ ha. While, minimum water required was maize in Western region with quantum of $6719 \mathrm{~m}^{3} / \mathrm{ha}$. In zaid pulse category, highest crop water requirement was noted in Central region with $6387 \mathrm{~m}^{3} / \mathrm{ha}$ and minimum crop water requirement in Western region with 5878 $\mathrm{m}^{3} / \mathrm{ha}$.

\section{Region-wise physical water productivity}

The results of region-wise physical water productivity for different crops grown in Uttar Pradesh is presented in table 2. Among the kharif cereal crops grown in the state, the highest water productivity was found for bajra crops with $1.749,1.248$ and $0.796 \mathrm{~kg} / \mathrm{m}^{3}$ in Eastern, Central and Bundelkhand region, respectively and in Western region it was found highest for maize crop $\left(1.67 \mathrm{~kg} / \mathrm{m}^{3}\right)$ and followed by the bajra crop. Whereas minimum water productivity was found for rice crop with $0.709,0.708$ and $0.313 \mathrm{~kg} / \mathrm{m}^{3}$ in Eastern, Central and Bundelkhand region, respectively. In the case of kharif pulses the maximum agronomic water productivity was observed in arhar crop and minimum in moong crop across all regions of the state. However, water productivity of all kharif pulses was found minimum ranging from 0.099 to $0.404 \mathrm{~kg} / \mathrm{m}^{3}$ in Western region as compared to other regions. 
Table.1 Region-wise consumptive water use for different crop $\left(\mathrm{m}^{3} / \mathrm{ha}\right)$

\begin{tabular}{|c|c|c|c|c|c|c|c|c|c|c|c|c|}
\hline \multirow[b]{2}{*}{ Crop } & \multicolumn{3}{|c|}{ Eastern } & \multicolumn{3}{|c|}{ Central } & \multicolumn{3}{|c|}{ Bundelkhand } & \multicolumn{3}{|c|}{ Western } \\
\hline & $\begin{array}{c}\text { Blue } \\
\text { Water }\end{array}$ & $\begin{array}{l}\text { Green } \\
\text { Water }\end{array}$ & $\begin{array}{c}\text { Total } \\
\text { Water }\end{array}$ & Blue Water & $\begin{array}{l}\text { Green } \\
\text { Water }\end{array}$ & $\begin{array}{c}\text { Total } \\
\text { Water }\end{array}$ & $\begin{array}{c}\text { Blue } \\
\text { Water }\end{array}$ & $\begin{array}{l}\text { Green } \\
\text { Water }\end{array}$ & $\begin{array}{c}\text { Total } \\
\text { Water }\end{array}$ & $\begin{array}{c}\text { Blue } \\
\text { Water }\end{array}$ & $\begin{array}{l}\text { Green } \\
\text { Water }\end{array}$ & $\begin{array}{c}\text { Total } \\
\text { Water }\end{array}$ \\
\hline Rice $(\mathrm{K})$ & 3389 & 5595 & 8985 & 3715 & 5207 & 8922 & 5316 & 3814 & 9130 & 3906 & 4862 & 8768 \\
\hline Rice $(Z)$ & 9603 & 1188 & 10791 & 10415 & 1045 & 11461 & 10135 & 1165 & 11300 & 9563 & 1036 & 10600 \\
\hline Maize $(\mathrm{K})$ & 1420 & 2907 & 4328 & 2189 & 600 & 2789 & 1987 & 2410 & 4397 & 1263 & 3242 & 4506 \\
\hline Maize $(Z)$ & 4967 & 2143 & 7110 & 5474 & 1804 & 7278 & 5204 & 2022 & 7226 & 5166 & 1552 & 6719 \\
\hline Jowar $(\mathrm{K})$ & 722 & 2949 & 3672 & 1125 & 2521 & 3646 & 1284 & 2434 & 3718 & 1164 & 2400 & 3565 \\
\hline Bajra $(\mathrm{K})$ & 722 & 2949 & 3672 & 1125 & 2521 & 3646 & 1284 & 2434 & 3718 & 1164 & 2400 & 3565 \\
\hline Small millets $(\mathrm{K})$ & 755 & 3025 & 3781 & 1156 & 2595 & 3751 & 1319 & 2505 & 3824 & 794 & 3008 & 3802 \\
\hline $\operatorname{Arhar}(\mathrm{K})$ & 540 & 3269 & 3809 & 870 & 2895 & 3765 & 1015 & 2804 & 3819 & 2382 & 1760 & 4142 \\
\hline Urd $(\mathrm{K})$ & 540 & 3269 & 3809 & 870 & 2895 & 3765 & 1015 & 2804 & 3819 & 2382 & 1760 & 4142 \\
\hline Urd (Z) & 5084 & 1114 & 6198 & 5501 & 886 & 6387 & 5231 & 1033 & 6264 & 4951 & 927 & 5878 \\
\hline Moong (K) & 540 & 3269 & 3809 & 870 & 2895 & 3765 & 1015 & 2804 & 3819 & 2382 & 1760 & 4142 \\
\hline Moong (Z) & 5084 & 1114 & 6198 & 5501 & 886 & 6387 & 5231 & 1033 & 6264 & 4951 & 927 & 5878 \\
\hline Moth $(\mathrm{K})$ & 540 & 3269 & 3809 & 870 & 2895 & 3765 & 1015 & 2804 & 3819 & 2382 & 1760 & 4142 \\
\hline Sesamum (K) & 1517 & 3079 & 4596 & 1750 & 2936 & 4686 & 1939 & 2849 & 4788 & 2438 & 2668 & 5106 \\
\hline Groundnut (K) & 1430 & 3196 & 4626 & 1856 & 2713 & 4570 & 2050 & 2631 & 4681 & 1585 & 3092 & 4677 \\
\hline Soybean $(\mathrm{K})$ & 1517 & 3079 & 4596 & 1750 & 2936 & 4686 & 1939 & 2849 & 4788 & 2438 & 2668 & 5106 \\
\hline Wheat (R) & 6959 & 1176 & 8136 & 7256 & 1018 & 8275 & 7357 & 929 & 8286 & 6583 & 968 & 7551 \\
\hline Barley (R) & 1847 & 532 & 2380 & 1841 & 537 & 2378 & 2041 & 415 & 2456 & 1793 & 425 & 2219 \\
\hline Gram (R) & 1754 & 502 & 2256 & 1833 & 464 & 2297 & 2043 & 366 & 2409 & 1723 & 375 & 2098 \\
\hline Peas and beans (R) & 1754 & 502 & 2256 & 1833 & 464 & 2297 & 2043 & 366 & 2409 & 1723 & 375 & 2098 \\
\hline Lentil (R) & 1754 & 502 & 2256 & 1833 & 464 & 2297 & 2043 & 366 & 2409 & 1723 & 375 & 2098 \\
\hline Rapeseed-mustard (R) & 5036 & 1814 & 6850 & 5489 & 1538 & 7027 & 5203 & 1751 & 6954 & 2736 & 2868 & 5605 \\
\hline Sunflower $(\mathrm{Z})$ & 5036 & 1814 & 6850 & 5489 & 1538 & 7027 & 5203 & 1751 & 6954 & 2736 & 2868 & 5605 \\
\hline Potato $(\mathrm{R})$ & 2297 & 636 & 2933 & 2426 & 577.5 & 3004 & 2737 & 461 & 3198 & 4274 & 1026 & 5300 \\
\hline Tobacco(R) & 1897 & 532 & 2429 & 2024 & 464 & 2488 & 2247 & 366 & 2613 & 1908 & 370 & 2278 \\
\hline Sugarcane (K) & 11278 & 4835 & 16113 & 12098 & 4352 & 16450 & 12247 & 6245 & 18492 & 10806 & 4694 & 15501 \\
\hline Cotton $(\mathrm{K})$ & 2395 & 4697 & 7092 & 2230 & 5225 & 7455 & 2183 & 5392 & 7575 & 3323 & 3564 & 6888 \\
\hline
\end{tabular}

Note: $K=$ kharif, $R=$ Rabi and $Z=$ zaid 
Table.2 Region-wise physical water productivity $\left(\mathrm{Kg} / \mathrm{M}^{3}\right)$ for different crops

\begin{tabular}{|c|c|c|c|c|c|c|c|c|c|c|c|c|}
\hline \multirow[b]{2}{*}{ Crop } & \multicolumn{3}{|c|}{ Eastern } & \multicolumn{3}{|c|}{ Central } & \multicolumn{3}{|c|}{ Bundelkhand } & \multicolumn{3}{|c|}{ Western } \\
\hline & $\begin{array}{c}\text { Irr. } \\
\text { Water } \\
\left(\mathrm{m}^{3} / \mathrm{ha}\right)\end{array}$ & $\begin{array}{c}\text { Crop } \\
\text { Yield } \\
(\mathrm{Kg} / \mathrm{ha})\end{array}$ & $\begin{array}{c}\text { Water } \\
\text { Productivity } \\
\left(\mathrm{Kg} / \mathrm{M}^{3}\right)\end{array}$ & $\begin{array}{c}\text { Irr. } \\
\text { Water } \\
\left(\mathrm{m}^{3} / \mathrm{ha}\right)\end{array}$ & $\begin{array}{c}\text { Crop } \\
\text { Yield } \\
\text { Kg/ha) }\end{array}$ & $\begin{array}{c}\text { Water } \\
\text { Productivity } \\
\left(\mathrm{Kg} / \mathrm{M}^{3}\right)\end{array}$ & $\begin{array}{c}\text { Irr. } \\
\text { Water } \\
\left(\mathrm{m}^{3} / \mathrm{ha}\right)\end{array}$ & $\begin{array}{l}\text { Crop } \\
\text { Yield } \\
\text { Kg/ha) }\end{array}$ & $\begin{array}{c}\text { Water } \\
\text { Productivity } \\
\left(\mathrm{Kg} / \mathrm{M}^{3}\right)\end{array}$ & $\begin{array}{c}\text { Irr. } \\
\text { Water } \\
\left(\mathrm{m}^{3} / \mathrm{ha}\right)\end{array}$ & $\begin{array}{c}\text { Crop } \\
\text { Yield } \\
\text { Kg/ha) }\end{array}$ & $\begin{array}{c}\text { Water } \\
\text { Productivity } \\
\left(\mathrm{Kg} / \mathrm{M}^{3}\right)\end{array}$ \\
\hline Rice $(\mathrm{K})$ & 3390 & 2402 & 0.709 & 3715 & 2632 & 0.708 & 5316 & 1665 & 0.313 & 3906 & 2353 & 0.603 \\
\hline Maize $(\mathrm{K})$ & 1421 & 1379 & 0.971 & 2189 & 1874 & 0.856 & 1987 & 1351 & 0.680 & 1264 & 2113 & 1.672 \\
\hline Jowar(K) & 723 & 961 & 1.329 & 1125 & 1120 & 0.996 & 1284 & 1015 & 0.790 & 1165 & 388 & 0.333 \\
\hline Bajra $(\mathrm{K})$ & 723 & 1264 & 1.749 & 1125 & 1404 & 1.248 & 1284 & 1022 & 0.796 & 1165 & 1488 & 1.278 \\
\hline Small Millets (K) & 755 & 784 & 1.039 & 1156 & 544 & 0.471 & 1319 & 824 & 0.625 & - & - & - \\
\hline Arhar (K) & 540 & 827 & 1.532 & 871 & 1019 & 1.171 & 1015 & 848 & 0.836 & 2383 & 962 & 0.404 \\
\hline Urd $(\mathrm{K})$ & 540 & 491 & 0.909 & 871 & 509 & 0.585 & 1015 & 372 & 0.367 & 2383 & 546 & 0.229 \\
\hline Moong (K) & 540 & 237 & 0.438 & 871 & 374 & 0.430 & 1015 & 330 & 0.325 & 2383 & 236 & 0.099 \\
\hline Sesamum $(\mathrm{K})$ & 1430 & 150 & 0.105 & 1857 & 123 & 0.066 & 2050 & 125 & 0.061 & 1585 & 96 & 0.061 \\
\hline Groundnut(K) & 1430 & 698 & 0.488 & 1857 & 812 & 0.437 & 2050 & 700 & 0.341 & 1585 & 548 & 0.346 \\
\hline Soybean $(\mathrm{K})$ & 1517 & 20 & 0.013 & 1750 & 926 & 0.529 & 1939 & 577 & 0.298 & 2438 & 570 & 0.234 \\
\hline Wheat (R) & 6959 & 2902 & 0.417 & 7257 & 3468 & 0.478 & 7357 & 2124 & 0.289 & 6583 & 3721 & 0.565 \\
\hline Barley $(\mathrm{R})$ & 1848 & 2609 & 1.412 & 1841 & 2692 & 1.462 & 2041 & 2702 & 1.324 & 1794 & 3184 & 1.775 \\
\hline $\operatorname{Gram}(\mathrm{R})$ & 1755 & 626 & 0.357 & 1833 & 545 & 0.297 & 2043 & 401 & 0.196 & 1724 & 516 & 0.299 \\
\hline Peas and beans (R) & 1755 & 763 & 0.435 & 1833 & 1262 & 0.688 & 2043 & 867 & 0.424 & 1724 & 1278 & 0.742 \\
\hline Lentil (R) & 1755 & 713 & 0.406 & 1833 & 701 & 0.382 & 2043 & 392 & 0.192 & 1724 & 1261 & 0.732 \\
\hline Rapeseed-mustard (R) & 5036 & 753 & 0.149 & 5489 & 908 & 0.165 & 5203 & 360 & 0.069 & 2737 & 1294 & 0.473 \\
\hline Linseed $(\mathrm{R})$ & 5036 & 306 & 0.061 & 5489 & 478 & 0.087 & 5203 & 478 & 0.092 & 2737 & 409 & 0.150 \\
\hline Rice $(Z)$ & 9603 & 2405 & 0.250 & 10416 & 2550 & 0.245 & - & - & - & 9564 & 2407 & 0.252 \\
\hline Maize (Z) & 4968 & 1804 & 0.363 & 5474 & 1837 & 0.336 & - & - & - & 5166 & 1847 & 0.357 \\
\hline Moong(Z) & 5084 & 628 & 0.123 & 5502 & 564 & 0.103 & 5231 & 676 & 0.129 & 4951 & 543 & 0.110 \\
\hline Urd (Z) & 5084 & 539 & 0.106 & 5502 & 607 & 0.110 & - & - & - & 4951 & 575 & 0.116 \\
\hline Sunflower (Z) & 5036 & 150 & 0.030 & 5489 & 1612 & 0.294 & 5203 & 1568 & 0.301 & 2737 & 1536 & 0.561 \\
\hline Potato(R) & 2298 & 17417 & 7.580 & 2427 & 18184 & 7.494 & 2737 & 21166 & 7.733 & 4275 & 21547 & 5.040 \\
\hline Tobacco(R) & 1898 & 4884 & 2.574 & 2024 & 5105 & 2.522 & 2247 & 557 & 0.248 & 1908 & 2484 & 1.302 \\
\hline Sugarcane (K) & 11278 & 59910 & 5.312 & 12098 & 59953 & 4.956 & 12247 & 42736 & 3.489 & 10807 & 63226 & 5.851 \\
\hline Cotton $(\mathrm{K})$ & 2395 & 214 & 0.089 & 2231 & 167 & 0.075 & - & - & - & 3324 & 234 & 0.070 \\
\hline
\end{tabular}

Note: $K=$ kharif, $R=$ Rabi and $Z=$ zaid 
Table.3 Comparative advantage of crops production in different regions of Uttar Pradesh

\begin{tabular}{|c|c|c|c|}
\hline \multirow[b]{2}{*}{$\begin{array}{l}\text { Name of the } \\
\text { Region }\end{array}$} & \multicolumn{3}{|c|}{ Comparative Advantage in Respect to } \\
\hline & Water Productivity & Crop Yield & $\begin{array}{c}\text { Crop Yield and Water } \\
\text { Productivity }\end{array}$ \\
\hline Eastern & $\begin{array}{l}\text { Rice (k), Jowar, Bajra, } \\
\text { Small millets, Arhar, } \\
\text { Urd (k), Moong (k), } \\
\text { Groundnut, Tobacco, } \\
\text { Cotton }\end{array}$ & & Gram, Sesamum \\
\hline Central & & $\begin{array}{l}\text { Rice, Jowar, Arhar, } \\
\text { Moong (k), Groundnut, } \\
\text { Linseed, Rice (z), Urd (z), } \\
\text { Sunflower, Potato, } \\
\text { Tobacco }\end{array}$ & Soybean \\
\hline Bundelkhand & Potato & Small millets, Linseed & Moong (z) \\
\hline Western & $\begin{array}{l}\text { Linseed, Rice (z), Urd } \\
\text { (z), Sunflower, }\end{array}$ & Bajra, Urd (k), Cotton & $\begin{array}{l}\text { Maize (k), Wheat, } \\
\text { Barley, Pea and beans, } \\
\text { Lentil, Rapeseed - } \\
\text { mustard, Maize (z), } \\
\text { Sugarcane }\end{array}$ \\
\hline
\end{tabular}

Note: $K=$ kharif, $R=$ Rabi and $Z=$ zaid

The water productivity was estimated for the sesamum (k) oilseed crop and it was realized to be $0.105,0.066,0.061$ and $0.61 \mathrm{~kg} / \mathrm{m}^{3}$ in the Eastern, Central, Bundelkhand and Western region, respectively. In case of groundnut $(\mathrm{k})$, physical water productivity was analyzed and recorded as $0.488,0.437$, 0.341 and $0.346 \mathrm{~kg} / \mathrm{m}^{3}$ in the Eastern, Central, Bundelkhand and Western region, respectively. The water productivity was computed for the soybean $(\mathrm{k})$ crop and maximum water productivity was found in Central region with the $0.529 \mathrm{~kg} / \mathrm{m}^{3}$ and minimum in Eastern region with $0.013 \mathrm{~kg} / \mathrm{m}^{3}$.

During rabi season wheat and barley crops were grown in the state and barley have higher water productivity than wheat crop. Water productivity in wheat crop was found to be $0.417,0.478,0.289$ and $0.565 \mathrm{~kg} / \mathrm{m}^{3}$ and similarly in barley crop it was estimated to be $1.412,1.462,1.324$ and $1.775 \mathrm{~kg} / \mathrm{m}^{3}$ in the Eastern, Central, Bundelkhand and Western region, respectively. The water productivity for gram was affirmed maximum in the Eastern region with $0.357 \mathrm{~kg} / \mathrm{m}^{3}$ and minimum in Bundelkhand region with 0.196 $\mathrm{kg} / \mathrm{m}^{3}$. The water productivity for lentil crop was found maximum in the Western region with $0.732 \mathrm{~kg} / \mathrm{m}^{3}$ and minimum in Bundelkhand region with $0.192 \mathrm{~kg} / \mathrm{m}^{3}$. In case of rabi oilseed crops (rapeseed-mustard and linseed) the water productivity was avowed maximum in Western region and minimum in Bundelkhand region.

Among the crops grown (rice, maize, moong, urd and sunflower) in zaid season in the state, the maize crop registered maximum water productivity in Eastern and Central region. In western region, the maximum water productivity found in sunflower and followed by the maize crop. However, only sunflower and moong crops are grown on scant area in Bundelkhand region. The cash crops viz. potato, tobacco, sugarcane and cotton were 
also grown in the state. Among these crops, maximum water productivity was found in potato with $7.580,7.45,7.733$ and 5.040 $\mathrm{kg} / \mathrm{m}^{3}$ in Eastern, Central, Bundelkhand and Western region, respectively. The minimum water productivity was registered in cotton crop in all the regions.

\section{Comparative advantage of regions for crop production}

The comparative advantage of crops production in different regions of Uttar Pradesh is presented in table 3. All the crops grown by farmers in different regions of Uttar Pradesh was categorized in three groups viz., (a) regions having higher agronomic water productivity; (b) regions having higher crop yield; and (c) regions having higher agronomic water productivity and crop yield. It was found that Eastern region has comparative advantage in respect of agronomic water productivity for rice, jowar, bajra, small millets, arhar, urd (k), moong (k), groundnut, tobacco and cotton, while gram and sesamum was displaying comparative advantage over other regions with respect to both water productivity and crop yield.

In Central region rice, jowar, arhar, moong $(\mathrm{k})$, groundnut, linseed, rice $(\mathrm{z})$, urd $(\mathrm{z})$, sunflower, potato and tobacco cultivation were found to be comparative advantage over other regions of Uttar Pradesh regarding crop yield point of view. Along with this, soybean cultivation in Central region has comparative advantage from both aspects i.e., water productivity and crop yield as compared to other regions of Uttar Pradesh.

With regard to Bundelkhand region, potato cultivation was found to be most attractive crop from the agronomic water productivity point of view, whereas cultivation of small millets and linseed were found comparative advantage over other regions of Uttar Pradesh from crop yield point of view. The moong (z) cultivation in Bundelkhand region has comparative advantage over other regions of Uttar Pradesh in respect of crop yield and agronomic water productivity.

In Western region cultivation of maize $(\mathrm{k})$, wheat, barley, pea and beans, lentil, rapeseedmustard, maize (z) and sugarcane crops has comparative advantage in respect of crop yield and agronomic water productivity point of view over the other regions of Uttar Pradesh. The region has comparative advantage for bajra, urd $(\mathrm{k})$ and cotton from crop yield point of view, whereas, linseed, rice $(\mathrm{z})$, urd $(\mathrm{z})$ and sunflower cultivation in western region has comparative advantage from agronomic water productivity point of view.

The results showed that among the kharif crops, highest crop water requirement was estimated for paddy crop in Bundelkhand region, whereas minimum crop water requirement was observed for jowar in Western region among all regions of the Uttar Pradesh. In rabi season, highest crop water requirement was estimated for wheat crop in Bundelkhand region and minimum water requirement was found for barley crop in Western region. The upper most crop water requirement for kharif pulses was in Western region while bottom most was in Central region among all regions. Among the kharif oilseed crops, groundnut was devouring highest crop water requirement in Bundelkhand region. In contrast, soybean was minimum water required crop in Eastern region. Among cash crops, sugarcane crop was registered highest crop water requirement in Bundelkhand region and tobacco crop have minimum water requirement in Western region.

The blue water, green water, total water demand and yield of crops across regions of 
the state were estimated, which provide the basis for a systematic appraisal of crop-water productivity. Along with other measures, scenario analysis of present study could be used to support the evaluation of the potential improvement in the regional and state water productivity and water use efficiency through regional cropping pattern adjustment and efficient irrigation technologies. The results also provides comprehensive decision support for researcher, policy makers and state development agencies for developing strategies for sustainable and alternative agricultural production systems for better resource use efficiency particularly water and maximizing farm net income. Furthermore, it provides a strong basis for further studies regarding the water and food security and the water resource management strategies in all the regions of Uttar Pradesh. Based on results, the following recommendation can be made for the water policies: [1] Cultivation of rice crop in kharif season and wheat crop in rabi season should be restricted up to a certain level which neither affect the water resources badly nor exert the pressure on stocks and supply of the crop produce; [2] Government should frame policy in such a manner that farmers are encourages to grow those crops which having comparative advantage in particular region to maximize crop production with minimum water use.

\section{References}

Allen, R.G.Pruitt, W.O., Wright, J.L., Howell, T.A., Venturae, F., Snyderf, R., Itenfisug, D., Stedutoh, P., Berengenai, J., Yrisarryj, J.B., Smithk, M., Pereiral, L.S., Raesm, D., Perriern, A., Alvesl, I., Waltero, L. and Elliott, R. 2006. A recommendation on standardized surface resistance for hourly calculation of reference ET0 by the FAO 56 Penman-Monteith method. Agricultural Water Management. 81(1-2): 1-22.
Allen, R.G., Richard, G.S., Luis,P., Raes, D. and Smith, M. 1998. Crop evapotranspiration - Guidelines for computing crop water requirements. FAO Irrigation and drainage paper 56, Food and Agriculture Organization Rome, Italy.

Carr, T., Yang, H. and Ray, C. 2016. Temporal variations of water productivity in irrigated corn: An analysis of factors influencing yield and water Use across Central Nebraska. PLoS ONE 11(8):1-17.

Anonymous. 2014. Dynamic Groundwater Resources of India, Central Ground Water Board, Ministry of Water Resources, River Development and Ganga Rejuvenation, Government of India.

Kijne, J.W., Tuong, T.P., Bennett, J., Bouman, B. and Oweis, $\mathrm{T}$. 2002.Challenge programme on water and food-background papers, Consultative Group on International Agricultural Research.

Kumar, D. M., Singh, O.P., Samad, M., Turral, H. and Purohit, C. 2008.Water Productivity of Irrigated Agriculture in India: Potential Areas for Improvement, published in proceedings of the $7^{\text {th }}$ Annual Partners' Meet on "Managing Water in the Face of Growing Scarcity, Inequity and Declining Returns: Exploring Fresh Approach, Volume-I: 121-140.

Lopez, U.R., Montoroa, A., Manasa, F., Lopez, F.P. and Fereres, E. 2012. Evapotranspiration and crop coefficients from lysimeter measurements of mature 'Tempranillo' wine grapes. Agricultural Water Management.112: 13-20.

Shah, T., Singh, O.P. and Mukherji, A. 2006. Some aspects of South Asia's Groundwater Irrigation Economy: Analyses from a Survey in India, 
Pakistan, Nepal terai and Bangladesh, Hydrogeology Journal. 14: 286-309.

Yihun, YM. 2015. Agricultural water productivity optimization for irrigated Teff (Eragrostic Tef) in water scarce semi-arid region of Ethiopia. Ph.D. Thesis, the Academic Board of Wageningen University and the Academic Board of the UNESCO-IHE
Institute for Water Education, Netherlands.

Zwart, S.J, Bastiaanssen, W.G.M., Fraiture, C. and Molden, D.J. 2010.A global benchmark map of water productivity for rainfed and irrigated wheat. Agricultural Management.97:1617-27.

\section{How to cite this article:}

Maina Kumari, O.P. Singh and Dinesh Chand Meena. 2017. Crop Water Requirement, Water Productivity and Comparative Advantage of Crop Production in Different Regions of Uttar Pradesh, India. Int.J.Curr.Microbiol.App.Sci. 6(7): 2043-2052. doi: https://doi.org/10.20546/ijcmas.2017.607.242 